\title{
https://journal.unram.ac.id/index.php/ifn
}

VOLUME 1, NOMOR 1, JUNI 2021

https://doi.org/10.29303/jfn.v1i1.156

\section{EVALUASI PENGGUNAAN TEPUNG IKAN SAPU-SAPU DALAM PAKAN BUATAN TERHADAP PERFORMA IKAN PATIN (Pangasius sp)}

\section{EVALUATION OF THE USE SUCKERMOUTH CATFISH MEAL IN ARTIFICIAL FEED TO THE PERFORMANCE OF CATFISH (Pangasius sp)}

\author{
Yuli Andriani ${ }^{*}$, Rita Rostika ${ }^{1}$ \\ ${ }^{1}$ Departemen Perikanan Fakultas Perikanan dan IImu Kelautan \\ Universitas Padjadjaran, Jatinangor 40600 \\ *Korespondensi email: yuli.andriani@unpad.ac.id
}

\begin{abstract}
ABSTRAK
Tepung ikan merupakan salah satu komponen pakan ikan yang memiliki harga tinggi, sehingga diperlukan upaya untuk mencari alternatif pengganti dari sumber alam sekitar sehingga harga pakan menjadi lebih ekonomis. Penelitian dilaksanakan di Hatchery Laboratorium Akuakultur, Fakultas Perikanan dan IImu Kelautan Universitas Padjadjaran, sedangkan analisis proksimat bahan pakan dan pakan uji, pembuatan tepung ikan sapu-sapu dilakukan Laboratorium Kimia dan Makanan Ternak Fakultas Peternakan Universitas Padjadjaran. Tujuan penelitian ini adalah untuk mengevaluasi penggunaan tepung ikan sapu-sapu dalam pakan buatan terhadap pertumbuhan dan kelangsungan ikan patin (Pangasius sp.) sebagai salah satu upaya alternatif penyediaan sumber protein dalam pakan ikan. Penelitian dilakukan dengan menggunakan Rancangan Acak Lengkap (RAL), terdiri dari 5 (lima) perlakuan dan masing-masing diulang 3 (tiga) kali. Perlakuan yang diberikan adalah penambahan tepung ikan sapu-sapu dalam pakan buatan sebanyak 0\%, 5\%, 10\%, 15\% dan 20\%. Parameter yang diamati pada akhir penelitian meliputi pertumbuhan mutlak, tingkat konsumsi dan kelangsungan hidup. Hasil penelitian menunjukkan bahwa penambahan tepung sapu-sapu sebesar $10 \%$ dalam pakan memberikan hasil terbaik, dimana pertumbuhan mutlak ikan patin sebesar $1.88 \mathrm{gram}$, konsumsi $10.46 \mathrm{gram} / \mathrm{hari}$, dan sintasan sebesar $97,7 \%$. Berdasarkan pengamatan, penggunaan tepung sapusapu sampai tingkat $20 \%$ dalam pakan tidak menimbulkan pengaruh negatif terhadap kelangsungan hidup ikan patin, sehingga dapat digunakan sebagai pengganti tepung ikan alternatif dalam pakan ikan.
\end{abstract}

Kata Kunci : Evaluasi, tepung ikan sapu-sapu, performa, pertumbuhan, Pangasius sp

\section{ABSTRACT}

Fishmeal is one component of fish feed that has a high price, so it takes efforts to find alternatives from natural sources around so that the price of feed becomes more economical. The research was conducted at hatchery aquaculture laboratory, Faculty of Fisheries and Marine Science Universitas Padjadjaran, while proximate analysis of 
feed materials and test feed, making Suckermouth Catfish meal conducted Laboratory of Chemistry and Livestock Food Faculty of Animal Husbandry Universitas Padjadjaran. The purpose of this study is to evaluate the use of Suckermouth Catfish meal in artificial feed against the growth and continuity of Pangasius $\mathrm{sp}$. as one of the alternative efforts to provide protein sources in fish feed. The research was conducted using a Complete Randomlzed Design (RAL), consisting of 5 (five) treatments and each repeated 3 (three) times. The treatment given is the addition of Suckermouth Catfish meal in artificial feed as much as $0 \%, 5 \%, 10 \%, 15 \%$ and $20 \%$. The parameters observed at the end of the study include absolute growth, consumption rate and survival. The results showed that the addition of Suckermouth Catfish meal by $10 \%$ in the feed gave the best results, where the absolute growth of Pangasius sp. by 1.88 grams, consumption of 10.46 grams / day, and sintasan by $97.7 \%$. Based on observations, the use of Suckermouth Catfish meal up to a level of $20 \%$ in feed does not cause a negative influence on the survival of Pangasius sp., so it can be used as a substitute for alternative fishmeal in fish feed.

Key words: Evaluation, Suckermouth Catfish meal, performance, growth, Pangasius $\mathrm{sp}$

\section{PENDAHULUAN}

Pakan merupakan salah satu komponen yang sangat menentukan keberhasilan dalam budidaya ikan. Kontribusi biaya pakan dapat mencapai hingga $60-80 \%$ dari total biaya produksi pada kegiatan budidaya intensif. Selama ini kecenderungan dari petani ikan adalah menggunakan pakan komersil yang dijual di pasaran karena bersifat lebih praktis dan efisien. Namun seiring dengan perubahan ekonomi global, terjadi beberapa kondisi yang mengakibatkan harga pakan komersil menjadi sangat mahal dan tidak terjangkau oleh petani ikan yang berskala kecil.

Sumber protein hewani yang umum digunakan sebagai salah satu bahan penyusun pakan adalah tepung ikan. Tepung ikan tidak saja digunakan dalam bidang perikanan, namun juga di bidang peternakan, sehingga penggunaan tepung ikan semakin dihadapkan pada kendala suplai dan harga. Dalam upaya memenuhi protein dalam pakan, perlu diusahakan alternatif bahan pakan lain yang bernilai gizi relatif sama untuk mengurangi penggunaan tepung ikan dalam pakan. Salah satu bahan yang dapat digunakan sebagai sumber protein hewani dalam pakan adalah tepung ikan sapu-sapu.

Ikan sapu-sapu merupakan salah satu ikan non ekonomis yang melimpah di perairan Jawa Barat, sehingga dapat diolah dan digunakan menjadi tepung ikan sapusapu. Tepung ikan sapu-sapu merupakan salah satu sumber protein hewani yang potensial untuk dikembangkan sebagai bahan pengganti tepung ikan. Berdasarkan hasil analisis proksimat diketahui bahwa nilai protein tepung ikan sapu-sapu berkisar antara 56,51-65,45\%. Hasil analisis tersebut menunjukkan bahwa tepung ikan sapusapu dapat dijadikan sumber protein hewani pakan karena kandungan protein kasarnya mendekati tepung ikan (47,85-55,57\%).

Penelitian tentang penggunaan tepung ikan sapu-sapu sebagai suplemen dalam pakan belum pernah dilakukan, sehingga perlu dilakukan pengkajian terlebih dahulu, sehingga dapat diketahui sampai seberapa jauh pengaruh penambahan tepung ikan sapu-sapu sebagai sumber protein terhadap pertumbuhan ikan, salah satunya pada ikan patin (Pangasius sp) yang merupakan salah satu komoditas penting di Indonesia. 


\section{METODE PENELITIAN}

Penelitian ini berlangsung selama 4 bulan, di Hatchery Laboratorium Akuakultur, Fakultas Perikanan dan IImu Kelautan Universitas Padjadjaran, sedangkan analisis proksimat bahan pakan dan pakan uji, pembuatan tepung ikan sapu-sapu dilakukan Laboratorium Kimia Makanan Ternak Fakultas Peternakan Universitas Padjadjaran.

Bahan dan alat yang digunakan dalam penelitian ini meliputi :

1. Ikan patin (Pangasius $\mathrm{sp}$ ) ukuran $10 \pm 0.5$ gram per ekor yang didapatkan dari daerah Jangari Cianjur sebanyak 250 ekor. Ikan yang digunakan untuk penelitian sebanyak 150 ekor, sedangkan 100 ekor dipelihara dalam wadah fiber sebagai ikan cadangan.

2. Tepung ikan sapu-sapu. Pengadaan tepung ikan sapu-sapu dilakukan dengan mengumpulkan ikan sapu-sapu dari perairan umum kemudian diolah menjadi tepung.

3. Pakan yang digunakan dalam penelitian ini berupa pelet, berkadar protein $35 \%$ untuk dengan persentase penambahan tepung sapu-sapu berbeda (Tabel 1), sedangkan kandungan rata-rata energinya yaitu $2840 \mathrm{kkal} \mathrm{EB/kg.} \mathrm{Analisis}$ proksimat dilakukan pada bahan-bahan pakan dan pada pakan percobaan yang diberikan pada ikan (Tabel 2).

Tabel 1. Komposisi proksimat (\%) bahan pakan penyusun pakan uji (dari bahan kering)

\begin{tabular}{|c|c|c|c|c|c|}
\hline \multirow{3}{*}{$\begin{array}{c}\text { Bahan Penyusun } \\
\text { Pakan }\end{array}$} & \multicolumn{5}{|c|}{ Pakan Uji } \\
\hline & $\mathrm{PO}$ & $\mathrm{P} 1$ & P2 & P3 & $\mathrm{P} 4$ \\
\hline & \multicolumn{5}{|c|}{$(\%)$} \\
\hline Tepung Ikan & 30 & 25 & 20 & 15 & 10 \\
\hline $\begin{array}{l}\text { Tepung ikan sapu- } \\
\text { sapu }\end{array}$ & 0 & 5 & 10 & 15 & 20 \\
\hline $\begin{array}{l}\text { Tepung bungkil } \\
\text { kedelai }\end{array}$ & 31 & 31 & 31 & 31 & 31 \\
\hline Bungkil kelapa & 9 & 9 & 9 & 9 & 9 \\
\hline Jagung kuning & 10 & 10 & 10 & 10 & 10 \\
\hline Dedak halus & 14 & 14 & 14 & 14 & 14 \\
\hline Minyak ikan & 2 & 2 & 2 & 2 & 2 \\
\hline Tepung terigu & 2 & 2 & 2 & 2 & 2 \\
\hline DCP & 0 & 0 & 0 & 0 & 0 \\
\hline Premix & 2 & 2 & 2 & 2 & 2 \\
\hline$\% \mathrm{BK}$ & 100,00 & 100,00 & 100,00 & 100,00 & 100,00 \\
\hline
\end{tabular}

Tabel 2. Nilai Gizi Pakan Uji

\begin{tabular}{llrrrrr}
\hline No & Zat makanan & A & B & C & D & E \\
\hline 1 & \% Protein kasar & 35,51 & 35,44 & 35,36 & 35,29 & 35,21 \\
2 & Lemak (\%) & 7,35 & 7,49 & 7,64 & 7,78 & 7,93 \\
3 & Serat kasar (\%) & 5,39 & 6,07 & 6,75 & 7,44 & 8,12 \\
4 & Calsium (\%) & 2,45 & 2,49 & 2,53 & 2,56 & 2,60 \\
5 & Pospor (\%) & 1,32 & 1,37 & 1,43 & 1,49 & 1,54 \\
6 & Lisine (\%) & 3,03 & 2,90 & 2,77 & 2,64 & 2,51 \\
\hline
\end{tabular}




\begin{tabular}{llrrrrr}
\hline 7 & Methionin (\%) & 0,83 & 0,79 & 0,76 & 0,72 & 0,69 \\
8 & Metionin $+\quad 1,40$ & 1,35 & 1,30 & 1,24 & 1,19 \\
& sistin & & & & & \\
9 & DE (kkal/kg) & 2840 & 2839 & 2839 & 2939 & 2838 \\
\hline
\end{tabular}

Percobaan dilakukan dengan menggunakan Rancangan Acak Lengkap

(RAL), terdiri dari 5 (lima) perlakuan dan masing-masing diulang 3 (tiga) kali, yaitu:

Perlakuan A: Pakan dengan penambahan $0 \%$ protein tepung ikan sapu-sapu

Perlakuan B: Pakan dengan penambahan 5\% protein tepung ikan sapu-sapu

Perlakuan C: Pakan dengan penambahan $10 \%$ protein tepung ikan sapu-sapu

Perlakuan D: Pakan dengan penambahan $15 \%$ protein tepung ikan sapu-sapu

Perlakuan E: Pakan dengan penambahan $20 \%$ protein tepung ikan sapu-sapu

Penempatan perlakuan pada percobaan ini dilakukan secara acak, sedangkan model rancangan yang digunakan adalah sebagai berikut:

Dimana:

$$
Y i j=\mu+\mathrm{Ti}+\varepsilon \mathrm{ij}
$$

Yij = nilai hasil pengamatan pada perlakuan ke-I ulangan ke-j

$\mu \quad=$ rata-rata respon seluruh perlakuan dan ulangan

$\mathrm{Ti} \quad=$ pengaruh perlakuan ke-l

घij = simpangan percobaan dari perlakuan ke-l dan ulangan ke-j

Pengaruh setiap perlakuan diuji dengan analisis statistik Uji F dan dilanjutkan dengan Uji Duncan untuk mengetahui perbedaan dari setiap perlakuan. Pakan diberikan dengan frekuensi tiga kali sehari, yaitu pada jam 08.00, 12.00 dan 16.00. Penimbangan ikan dilakukan setiap satu minggu sekali. Selanjutnya dilakukan penyesuaian untuk jumlah pada pemberian pakan berikutnya. Pengukuran kualitas air ( $\mathrm{pH}$, suhu, oksigen terlarut dan ammonia) dilakukan sebanyak 3 kali selama masa penelitian, yaitu pada awal, tengah dan akhir penelitian. Parameter pengamatan yang akan dikumpulkan dan dianalisis, meliputi:

\section{Konsumsi Pakan}

Konsumsi Bahan kering pakan (g/hari) $=$

Keluaran bahan kering feses (g/hari)/Ketidakcernaan $\times 100 \%$

(Sumber: Ranjhan, 1980; Schneider, 1973)

\section{Pertumbuhan Mutlak}

Dimana:

$$
\mathrm{PM}=[\mathrm{Wt}-\mathrm{Wo}]
$$

$\mathrm{PM} \quad=$ pertumbuhan mutlak $(\mathrm{g})$

Wt $\quad=$ bobot ikan pada akhir penelitian $(\mathrm{g})$

Wo $=$ bobot ikan pada awal penelitian $(\mathrm{g})$

\section{Laju Sintasan}

$$
\mathrm{S} \quad=\frac{\mathrm{Nt}}{\mathrm{No}} \times 100 \% \quad \text { (Sumber: Effendi, 1979) }
$$

Dimana:

$\mathrm{S} \quad=$ laju sintasan

$\mathrm{Nt} \quad=$ jumlah benih ikan yang hidup pada akhir penelitian (ekor) 
No = jumlah benih ikan yang hidup pada awal penelitian (ekor)

HASIL

\section{Konsumsi Pakan}

Rata-rata konsumsi harian ikan patin pada masing-masing perlakuan selama penelitian disajikan pada Gambar 1. Hasil analisis ragam menunjukkan bahwa terdapat pengaruh perlakuan terhadap konsumsi harian ikan patin (Tabel 3).

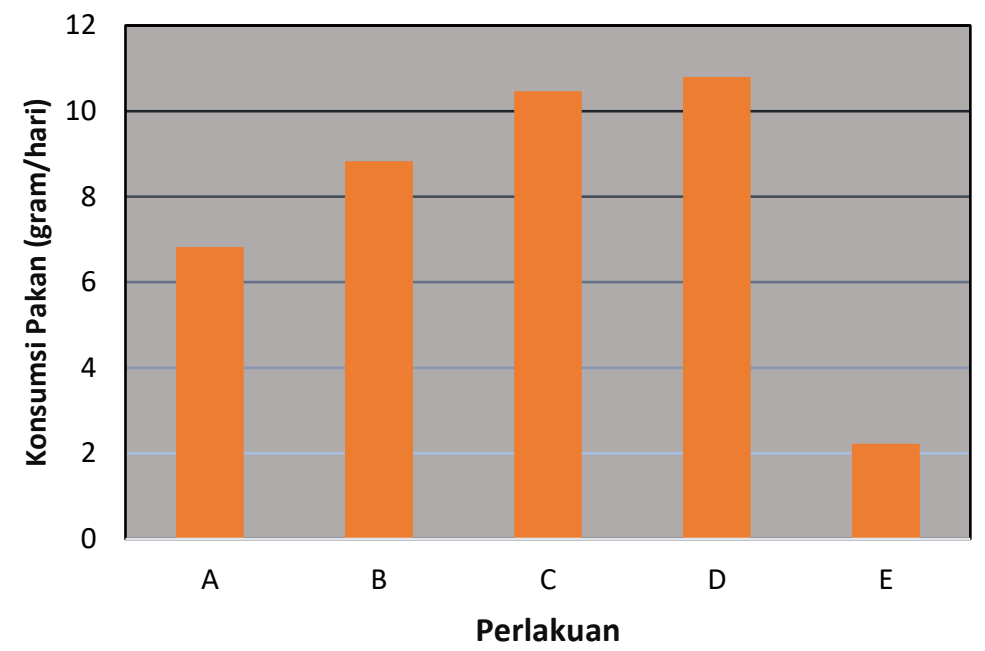

Gambar 1. Rata-Rata Konsumsi Harian Ikan Patin Selama Penelitian

Tabel 3. Hasil Uji Duncan Pengaruh Perlakuan Terhadap Konsumsi Pakan Ikan Patin (gram/hari).

Perlakuan

Rata-rata Konsumsi

Signifikansi $(0,05)$

(gram/hari)

\begin{tabular}{ccc}
\hline A & 6,82 & $\mathrm{a}$ \\
B & 8,83 & $\mathrm{a}$ \\
C & 10,46 & $\mathrm{~b}$ \\
D & 10,79 & $\mathrm{~b}$ \\
E & 2,223 & $\mathrm{C}$
\end{tabular}

Keterangan: Nilai dengan huruf yang berbeda pada kolom yang sama berbeda sangat nyata $(P<0,05)$. 


\section{Pertumbuhan Mutlak}

Laju pertumbuhan ikan patin disajikan pada Gambar 2.

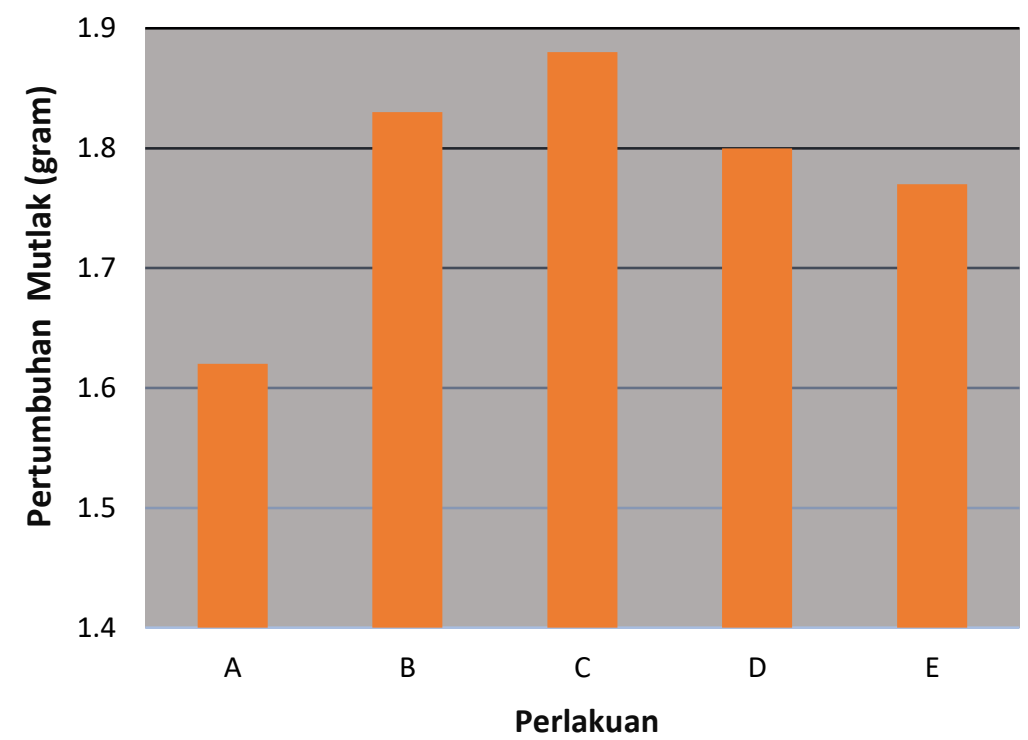

Gambar 2. Pertumbuhan Mutlak Ikan Patin Selama Penelitian

Dari analisis ragam diperoleh bahwa penambahan tepung sapu-sapu dengan persentase berbeda dalam pakan buatan tidak berpengaruh nyata terhadap laju pertumbuhan mutlak ikan patin. Data pada gambar diatas memperlihatkan bahwa pertumbuha mutlak ikan patin meningkat sejalan dengan penambahan tepung sapusapu sampai batas tertentu kemudian pertumbuhan tersebut mengalami menurun pada tingkat penambahan yang lebih tinggi.

Tabel 4. Hasil Uji Duncan Pengaruh Perlakuan Terhadap Pertumbuhan Mutlak Ikan Patin (gram).

\begin{tabular}{ccc}
\hline Perlakuan & $\begin{array}{c}\text { Pertumbuhan mutlak } \\
(\text { gram })\end{array}$ & Signifikansi $(0,05)$ \\
\hline A & 1,62 & a \\
B & 1,83 & a \\
C & 1,88 & a \\
D & 1,80 & a \\
E & 1,77 & a
\end{tabular}

Keterangan: Nilai dengan huruf yang berbeda pada kolom yang sama berbeda sangat nyata $(\mathrm{P}<0,05)$

\section{Laju Sintasan}

Berdasarkan analisis ragam diperoleh bahwa penambahan tepung sapu-sapu dengan persentase berbeda dalam pakan tidak menunjukkan perbedaan yang nyata $(P<0,05)$ terhadap laju sintasan ikan patin (Tabel 5).

Tabel 5. Laju sintasan (\%) ikan patin untuk setiap pengamatan selama penelitian.

\begin{tabular}{ccc}
\hline Perlakuan & Laju sintasan $(\%)$ & Signifikansi $(0,05)$ \\
\hline A & 95,55 & a \\
B & 97,77 & a \\
C & 97,77 & a \\
D & 100 & a
\end{tabular}


E

\begin{tabular}{llllll}
\multicolumn{1}{c}{ E } & \multicolumn{2}{c}{97,77} & \multicolumn{1}{c}{ a } \\
\cline { 2 - 6 } \begin{tabular}{c} 
Tabel 6. Data hasil pengukuran beberapa parameter kualitas air \\
\multirow{2}{*}{$\begin{array}{c}\text { Parameter } \\
\text { Kualitas Air }\end{array}$}
\end{tabular} & \multicolumn{5}{c}{ Perlakuan } \\
\cline { 2 - 6 } & \multicolumn{1}{c}{ A } & \multicolumn{1}{c}{ B } & \multicolumn{1}{c}{ C } & \multicolumn{1}{c}{ D } & \multicolumn{1}{c}{ E } \\
\hline Suhu $\left({ }^{\circ} \mathrm{C}\right)$ & $26,5-29$ & $26,0-28.5$ & $26,0-28.5$ & $26,0-28.5$ & $26,0-$ \\
& & & & & 28.5 \\
Oksigen terlarut & $6,00-$ & $6,20-$ & $6,30-7,20$ & $5,5-7,0$ & $5,25-$ \\
$(\mathrm{mg} / \mathrm{L})$ & 7,0 & 7,0 & & & 6,9 \\
$\mathrm{pH}$ & $6,5-6,9$ & $6,5-6,8$ & $6,7-6,9$ & $6,6-6,9$ & $6,7-6,9$ \\
Alkalinitas (mg/l) & $12,5-19,5$ & $12,9-19,5$ & $12,7-16,0$ & $13,4-19,0$ & $14,0-20$ \\
CaCO3(eq) & & & & & \\
Amonia (mg/l) & $0,05-0,17$ & $0,05-0,16$ & $0,06-0,17$ & $0,07-0,18$ & $0,05-$ \\
& & & & & 0,10 \\
\hline
\end{tabular}

\section{PEMBAHASAN}

\section{Konsumsi Pakan}

Rata-rata konsumsi pakan tertinggi pada ikan patin konsumsi pakan tertinggi terdapat pada penambahan tepung ikan sapu sapu sebesar 10\% yaitu $10,46 \mathrm{gram} / \mathrm{hari}$, dan terendah pada penambahan $20 \%$ yaitu $2,223 \mathrm{gram} / \mathrm{hari}$. Rendahnya konsumsi pakan pada penambahan tepung sapu-sapu yang semakin banyak berkaitan dengan palatabilitas pakan. Hoar (1979) menyatakan bahwa faktorfaktor yang mempengaruhi jumlah konsumsi pakan pada ikan adalah: feeding habit, status fisiologis, berat ikan, suhu, kosentrasi oksigen, komposisi pakan dan palatabilitas. Hasil pengamatan selama penelitian menunjukkan respon ikan terhadap pakan semakin menurun pada penambahan tepung sapu-sapu yang semakin tinggi. Tingkat kesukaan yang rendah diduga berkaitan dengan dua hal. Pertama, kandungan asam amino yang semakin rendah sejalan dengan peningkatan persentase tepung cacing dalam pakan. Secara umum kandungan asam amino dalam tepung sapu-sapui nilainya lebih rendah daripada tepung ikan, sehingga peningkatan persentase tepung sapu-sapu dalam pakan mengakibatkan pakan kekurangan asam amino esensial. Lebih lanjut Jauncey dan Ross (1982) menyatakan bahwa pakan yang mengalami defisiensi asam amino esensial akan mengakibatkan palatabilitas pakan menurun, sehingga pada gilirannya menurunkan nafsu makan.

Faktor kedua yang mempengaruhi rendahnya konsumsi terhadap pakan disebabkan bau atau aroma pakan yang tidak menyenangkan bagi ikan, sehingga mempengaruhi palatabilitas. Palatabilitas merupakan faktor penting yang turut menentukan tingkat konsumsi pakan, dan dipengaruhi oleh aroma, rasa dan tekstur dari pakan (Church 1979 dalam Supriadi 1999). Tepung ikan memiliki aroma yang khas dalam pakan sehingga meningkatkan respon ikan untuk mengkonsumsi pakan yang diberikan. Ada kecenderungan semakin tinggi kandungan tepung sapu-sapu dalam pakan, semakin rendah pula palatabilitas pakan, sehingga tingkat konsumsi ikan menjadi menurun. Meskipun hasil pengujian karakteristik fisik pellet menunjukkan bahwa pellet tepung sapu-sapu tidak berbau, penambahan tepung sapu-sapu dalam pakan pada kenyataannya mempengaruhi aroma pakan, yang pada gilirannya mempengaruhi palatabilitas dan konsumsi pakan.

Pakan yang diberi penambahan tepung sapu-sapu sebesar $20 \%$ memiliki kandungan asam amino yang lebih rendah daripada keempat perlakuan lainnya, sehingga menghasilkan aroma khas yang tidak sesuai dengan selera ikan. Aroma 
pakan dalam hal ini ditentukan oleh kualitas protein dalam pakan, salah satunya asam amino yang membentuk protein dalam pakan (Atema 1980 dalam Supriadi 1999). Menurut (Buwono 2000) Asam amino dengan komposisi yang seimbang dalam pakan dengan komposisi asam amino yang terdapat dalam tubuh ikan akan menyebabkan ikan dapat tumbuh dengan normal.

Perbedaan konsumsi pakan kemungkinan dipengaruhi oleh kecernaan pakan. Meningkatnya kecernaan pakan berperan dalam meningkatkan konsumsi pakan. Kondisi ini sesuai dengan pendapat Tillman et al. (1987) bahwa pakan yang mempunyai kecernaan tinggi akan lebih cepat meninggalkan saluran pencernaan, sehingga lebih banyak ruangan yang tersedia untuk penambahan konsumsi pakan. Sedangkan pakan dengan kecernaan rendah memungkinkan penyerapan zat-zat makanan lebih lambat sehingga konsumsi pakan akan berkurang.

\section{Pertumbuhan Mutlak}

Pertumbuhan mutlak tertinggi didapatkan pada perlakuan penambahan tepung sapu-sapu sebasar $10 \%$ (1,88 gram), dan yang terendah pada penambahan $0 \%$ yaitu sebasar 1,62 gram. Penggunaan tepung cacing $20 \%$ dalam pakan sangat nyata menurunkan pertumbuhan ikan dibandingkan 0\%, 5\%, 10\% dan 15\%. Menurunnya laju pertumbuhan ikan sejalan dengan meningkatnya kandungan tepung sapu-sapu dalam pakan. Hal ini berhubungan dengan kecernaan bahan kering pakan yang semakin menurun pada penggunaan tepung sapu-sapu dengan persentase yang lebih tinggi Data ketidakcernaan bahan kering pakan seluruh perlakuan dapat dilihat pada Lampiran. Dari data tersebut dapat diketahui kecernaan bahan kering pakan yang diberi penambahan tepung cacing sebesar $0 \%, 5 \%, 10 \%, 15 \%$ dan $20 \%$ nilanya semakin menurun. Semakin menurunnya nilai kecernaan pakan akan mengakibatkan ketersediaan energi, asam amino dan lemak semakin rendah, dan selanjutnya akan menurunkan laju pertumbuhan. Pakan yang memiliki kecernaan yang rendah akan menyebabkan zat-zat makanan yang seharusnya dimanfaatkan oleh tubuh keluar bersama feses.

Enzim, cairan pencernaan dan sel epithel usus membantu protein, polisakarida, lemak dan asam nukleat untuk didegradasi menjadi molekul yang lebih sederhana sehingga dapat diserap dan diasimilasi oleh tubuh ikan. Tetapi ada beberapa jenis protein dan polisakarida yang tidak dapat didegradasi.

Pada system pencernaan ikan, setiap makanan memiliki tingkat kecernaan yang berbeda. Perubahan jenis makanan dari alami menjadi pakan buatan akan merubah waktu pengosongan lambung menjadi lebih lama. Untuk itu disarankan pembuatan pakan buatan harus disesuaikan dengan pakan alaminya sehingga tidak merubah waktu pengosongan lambung.

Salah satu faktor yang mempengaruhi kecernaan pakan adalah kandungan serat kasar yang terkandung dalam pakan tesebut. Kandungan serat kasar dalam lima pakan perlakuan relatif sama (2,210-2,219\%), namum kandungan lignin pada penambahan tepung sapu-sapu sebesar $20 \%$ paling tinggi $(5,92 \%)$, sementara penambahan tepung sapu-sapu sebesar $0 \%, 5 \%, 10 \%$ dan $15 \%$ berturut-turut 3,65\%, $3,68 \%, 3,70 \%, 3,82 \% \quad$ Peningkatan kandungan lignin dalam pakan diduga akan meningkatkan senyawa ADIN (Acid Detergent Insoluble Nitrogen) yang merupakan ikatan lignin dan protein, sehingga penyerapan $\mathrm{N}$ berkurang serta jumlah komponen serat kasar tidak tercerna (Acid Detergent Fiber) meningkat.

Komposisi asam amino terutama asam amino esensial dari pakan juga akan mempengaruhi pertumbuhan ikan. Menurut Shigueno (1975), pakan yang baik untuk pertumbuhan adalah pakan yang memiliki pola asam amino yang hamper sama 
dengan pola asam amino tubuh ikan. Apabila dilihat dari perbandingan komposisi asam amino tepung ikan dan tepung ikan sapu sapu (Tabel1), tepung sapu-sapu memiliki asam amino yang lengkap namun nilai dan jumlahnya lebih rendah dari tepung ikan.

Perbedaan kandungan asam amino esensial pada setiap perlakuan mempengaruhi pertumbuhan ikan gurame. Penambahan tepung sapu-sapu sebesar $10 \%$ menghasilkan pertumbuhan tertinggi (6,537 gr), sementara peningkatan persentase tepung sapu-sapu sebesar $15 \%$ dan $20 \%$ mengakibatkan laju pertumbuhan menurun. Diduga penambahan tepung sapu-sapu sebanyak $10 \%$ mempunyai komposisi pakan terbaik, dimana terjadi proses saling mengisi yang seimbang dari kedua sumber protein hewani tersebut. Hal ini sejalan dengan pernyataan Crampton (1969) apabila dua atau lebih dari dua protein yang mengandung asam-asam amino berbeda diberikan pada hewan, maka asam-asam amino tersebut saling mengisi sehingga terbentuk pola pakan yang sempurna. Keragaman antar bahan penyusun menyebabkan adanya efek saling melengkapi antar komponen gizi dan mempengaruhi metabolisme protein pakan dalam tubuh ikan.

Asam amino yang paling rendah persentasenya dalam tepung sapu-sapu adalah metionin $(0,08 \%)$, relatif lebih rendah dari tepung ikan $(1,57 \%)$. Hal ini mengakibatkan ketersediaan metionin semakin berkurang sejalan dengan peningkatan kandungan tepung sapu-sapu dalam pakan. Metionin merupakan asam amino esensial mengandung belerang yang memiliki peran penting dalam pertumbuhan ikan. Proses penyerapan asam amino ke dinding sel diaktifkan dengan metionin sebagai precursor, sehingga mempercepat gerak penyerapan dari asamasam amino lain (Scott et al., 1982). Defisiensi metionin dalam pakan juga mempengaruhi keseimbangan asam-asam amino pakan.

Hasil penelitian ini sejalan dengan penelitian Rachmawati (1996) terhadap ikan ikan gurame umur 40 hari yang menyimpulkan bahwa penambahan tepung cacing terbaik yang dapat dicampurkan dalam pakan adalah $25 \%$. Sementara penambahan yang lebih banyak akan menurunkan pertumbuhan, retensi protein dan lemak, kecernaan pakan, serta laju sintasan ikan.

\section{Laju Sintasan}

Laju sintasan ikan patin berkisar antara 95,55-100\%. Tidak adanya perbedaan yang berarti pada perlakuan ini karena secara umum penambahan tepung sapu-sapu dalam pakan tidak menimbulkan efek lethal terhadap ikan. Pertumbuhan ikan akan terganggu apabila kandungan protein dalam pakan sedikit (Makmur 2004). Faktor lain yang berpengaruh terhadap laju sintasan adalah kondisi media pemeliharaan ikan. Pada penelitian ini suhu, kepadatan dan kualitas air diupayakan mendukung laju sintasan yang maksimal. Ikan-ikan percobaan dipelihara dalam ruangan yang memiliki suhu yang terkontrol dan relatif stabil, kepadatan yang rendah, pemberian aerasi, penyiponan dan penggantian air yang berkala. Dengan demikian laju sintasan yang diperoleh pada penelitian ini benar-benar menggambarkan pengaruh perlakuan pada ikan percobaan. Adapun hasil pengukuran beberapa parameter kualitas air selama penelitian dapat dilihat pada (Tabel 6). Menunjukkan bahwa kisaran nilai kualitas air media pemeliharaan ikan selama penelitian berlangsung masih berada dalam kisaran yang sesuai untuk menunjang pertumbuhan ikan. Laju sintasan yang diperoleh dalam penelitian ini lebih tinggi apabila dibandingkan dengan laju sintasan pada penelitian Rachmawati (1996). Hal ini kemungkinan disebabkan perbedaan sumber dan jumlah protein, serta ukuran ikan yang digunakan. 


\section{KESIMPULAN}

1. Penambahan tepung sapu-sapu sebesar $10 \%$ dalam pakan menghasilkan performa terbaik pada ikan patin, meliputi pertumbuhan mutlak sebesar 1.88 gram, konsumsi 10.46 gram/hari, dan sintasan sebesar $97,7 \%$.

2. Penggunaan tepung sapu-sapu sampai tingkat $20 \%$ dalam pakan tidak menimbulkan pengaruh negatif terhadap kelangsungan hidup ikan patin.

\section{DAFTAR PUSTAKA}

Buwono, I.D. 2000. Kebutuhan Asam Amino Essensial Dalam Ransum Ikan. Buku Seri Perikanan. Penerbit Kanisius, Yogyakarta.

Crampton, E. W., L. E. Haris. 1969. Applied Animal Nutrition. $2^{\text {nd }}$ Ed. W. H. Freeman and Co. San Franscisco. Page 62-128.

Effendie, M.I. 1979. Biologi Perikanan. Yayasan Pustaka Nusantara. 163 hal.

Hoar, W. S., Randal, D. J., dan Brett, J. R 1979. Fish Physiology. Academic Press. New York.

Jauncey, K., Ross, B. 1982. A Guide to Tilapia Feed and Feeding. Institute of Aquaculture. University of Stirling. Scotland. $111 \mathrm{pp}$

Makmur, S. 2004. Proses Metabolisme Protein Pakan pada Ikan. Warta Perikanan Indonesia. 10(3): 14-16.

Rachmawati, D. 1996. Pengaruh Penggunaan Tepung Cacing Tanah (Lumbricus rubellus) Sebagai Sumber Protein Hewani Dalam Pakan Buatan Terhadap Pertumbuhan Benih Ikan Gurame (Osphronemus gouramy Lac.). Tesis. Tidak dipublikasikan. Program Pascasarjana IPB.

Ranjhan. S. K. 1980. Animal Nutrition in Tropics, $2^{\text {nd }}$ Revised Edition. Vicas Publishing House PVT. Ltd, New Delhi.

Schneider, B. H., W.P. Flatt. 1973. The Evaluation of Feeds Through Digestibility Experiment. The University of Georgia Press. New York.

Scott, M. L., M. C. Neisheim., R. J. Young. 1982. Nutrition of The Chickens. $2^{\text {nd }}$ Ed. Publishing by: M.L. Scott and Assoc. Ithaca, New York.

Shigueno, K. 1975. Shrimp Culture In Japan (p. 153). Tokyo: Association for International Technical Promotion.

Supriadi dan Sukamto. 1999. Mikrobiologi. Pengolahan dan Keamanan Pangan. Jakarta: Alumni.

Tillman, A. D., H. Hartadi, S. Reksohadiprodjo, S. Prawirokusumo dan S. Lebdosoekojo. 1998. Ilmu Makanan Ternak Dasar. Gadjah Mada University Press, Yogyakarta. 